\title{
Factors Influencing Farmers' Decision to Adopt Apple Management Practices in Southwestern Highlands, Uganda
}

\author{
Ambrose Rwaheru Aheisibwe $^{1 *} \quad$ Kenneth Tindimwebwa $^{2} \quad$ Denis Ashaba $^{3} \quad$ Alex Barekye $^{3}$ \\ 1.Makerere University Business School, Department of Accounting and Finance, Kampala, Uganda \\ 2.Kyambogo University, Department of Economics and Statistics, Kampala, Uganda \\ 3.National Agricultural Research Organization, Kachwekano ZARDI, Kabale, Uganda
}

\begin{abstract}
Worldwide apples account for fifty (50) percent of the world's deciduous fruit tree production. Despite the benefits that come with apple production, adoption has been slow especially among smallholder farmers in Southwestern Highlands. This present study was therefore conducted to identify apple management practices (AMPs) and also examine the factors influencing farmer decision to adopt AMPs. A multi-stage sampling procedure was employed to select 52 apple growing households in the districts of Kabale, Kisoro, Kanungu and Rukungiri that form Southwestern Highlands. Probit regression model was employed and the estimation procedure followed Maximum Likelihood Estimation (MLE) approach. Results from the descriptive statistics indicated that the most applied management practices included weeding, bending and staking, pesticide application and defoliation among others. Probit regression results showed that sex of the farmer, average number of fruits per tree, household labor force, farm size and access to credit had a positive and statistically significant effect on farmers' decision to adopt AMPs $(p<0.05)$ while age of the farmer, orchard location, obstruction by birds and off-farm income source had a negative and statistically significant influence on farmers' decision to adopt AMPs $(\mathrm{p}<0.05)$. In view of the above, there is need to identify and address gender differences in terms of engagement in apple production targeting more women. Research needs to come up with an effective but affordable remedy against pests especially birds, strategies of attracting and maintaining youth into apple farming need to be explored and implemented since apple farming is labor intensive and is dominated by aging farmers, research and extension need to explore appropriate and cost effective avenues for farmers to access credit, accurate and quality agricultural information.
\end{abstract}

Keywords: Adoption, Apples, Probit model, Orchard, Southwestern Highlands

DOI: $10.7176 / \mathrm{JESD} / 10-2-14$

\section{Introduction}

Apple (Malus domestica Borkh) is a deciduous fruit grown across the world because of its diverse uses, high dietary and health benefits (Adima et al., 2016; Busdieker-Jesse et al., 2016). China is the leading apple producer in the world. It accounts for annual production of approximately 39.7 million tonnes of fresh apple fruit harvested on 2.41 million hectare of land (Wang et al., 2016; FAO, 2016). The European Union (EU) and the United states are the $2^{\text {nd }}$ and $3^{\text {rd }}$ largest world producers of apples (FAO, 2016) respectively. In Africa the major producing countries include; South Africa (649218 tonnes), Morocco (466,437 tonnes), Egypt (436,931 tonnes), Algeria 364,750 tonnes and Tunisia (96,000 tonnes) contributing 1.43 percent of the world production (FAOSTAT, 2013). In Uganda, the apple industry started in 1999 when the Forestry Resources Research Institute (FORRI) and Kawanda Agricultural Research Institute (KARI) initiated trials in the Southwestern Highlands of Uganda, with the aim of offering farmers an alternative source of income (ICRAF, 2003b; Byarugaba et al., 2013). Over the last 7 years, temperate fruit types namely apples, pears, peaches, nectarines, plums, grapes and figs were introduced for evaluation in Uganda (Namirembe et al., 2006). At present, apple production lies with smallholder family farmers in Southwestern Uganda. The Southwestern Highlands were chosen as the preferred location for evaluation of these fruits because of the favourable climate characterised by temperatures of $10-30^{\circ} \mathrm{C}$ and abundant rainfall that ranges between $600 \mathrm{~mm}$ to $2260 \mathrm{~mm}$ (Kashaija \& Wagoire, 2008). The temperate fruits that have been evaluated, apples and pears show potential for adaptability and economic productivity in the highlands (Turyomurugyendo et al., 2004; Chemining'wa et al., 2005). Adoption of new technologies can be a feasible option for enhancing household incomes and welfare (Chandio \& Yuansheng, 2018). Although apple enterprise has become a gainful cash crop for the people of Southwestern Uganda, its production is still challenging especially on the side of growers due to the perennial nature of the crop and hence its production is still at a subsistence level.

The enterprise has over the years seen increasing investments in production, purchase and distribution of apple seedlings to farmers across the Southwestern Highlands in order to foster adoption of apple growing for income generation. Nonetheless, apple management practices applied by farmers are yet to be identified and the extent to which the factors that influence farmers' decision to adopt AMPs are yet to be known. As a result, the country has continued to rely on importation of the fruits from Kenya and-South-Africa to meet the increasing domestic demand (MAAIF, 2012). Each year, Uganda roughly loses over 73 billion shillings importing apple 
fruits without considering juices and other concentrates (MAAIF, 2012; Aheisibwe et al., 2017). This study was therefore undertaken to identify apple management practices and also examine the factors that influence farmers' decision to adopt AMPs in the Southwestern Highlands of Uganda. The empirical results obtained will not only serve as a reference for the future researchers but will also benefit MAAIF and its agencies through policy implications on how to enhance apple productivity and wider adoption of apple management practices by smallholder farmers.

\section{Materials and Methods}

\subsection{Study Area and Population}

The population of this study comprised of 100 apple farming households from which a sample of 52 was selected from the districts of Kabale, Kisoro, Kanungu, and Rukungiri in Southwestern Highlands (Figure 1). The Southwestern Highland is predominantly high altitude ranging from $1200 \mathrm{~m}$ to $2350 \mathrm{~m}$ above sea level. The area has agro-climatic conditions that favor a wide range of crops and livestock, as a major source of livelihood for the inhabitants (Kashaija \& Wagoire, 2008). The zone receives bimodal rainfall pattern ranging from $1000-$ $1500 \mathrm{~mm}$ and temperature range is $10-30{ }^{\circ} \mathrm{C}$. According to Chemining'wa et al. (2005), soils in Southwestern Highlands are acidic to slightly acidic loams, reddish brown clay loams, humus loams and yellowish red clay loams with generally a good nutrient supply and with natural fertility and good drainage. The variations in cropping systems are result of the differences in agro-ecological conditions and socio-economic endowments within the districts in the zone.

\subsection{Sample size and Sampling Strategy}

The study was carried out on 52 apple farming households that were spread in the districts of Kanungu, Kabale, Kisoro and Rukungiri. The study used multi-stage sampling technique. The first stage was purposive selection of four (4) districts and at least two (2) sub-counties in each district on the basis of concentration of apple production. The second stage involved purposive selection of two (2) parishes from each of the apple producing sub-counties. The third and final stage involved random selection of at least 50 percent of apple producers from each parish, making a total of 52 apple farming households (Table 1).

\subsection{Study design, Data collection and Procedure}

A survey of apple farming households from the four (4) districts of Southwestern Highlands of Uganda was designed to generate detailed information. The study used primary data that were collected with the use of semi-structured questionnaires and interview guides. The questionnaire was designed and pre-tested in the field to ensure relevance of questions, time duration for conducting an interview, clarity of questions and efficacy of the interviewing language. Pre-testing was done on 10 apple farming households in Kanyabitara parish, Bubare sub-county in Kabale district that was not included on the study list. The results of the pre-test helped to further fine-tune the questionnaire. For instance based on the results of the pretesting, the order of items in the questionnaire was modified to improve the logical flow of the interview. Data were collected on apple yield (number of fruits per tree), input usage, socio-economic, farm specific and institutional variables (Table 2).

\subsection{Analytical Framework}

In investigating the factors affecting farmers' decision to adopt apple best management practices, a probit model has been found to be useful in many studies due to its binary response (Fadare et al., 2014; Subedi et al., 2017). A probit model is most preferred than others due to its good properties particularly the normal distribution assumption (Wooldridge, 2010). In the probit model, a farmer $\boldsymbol{i}$ is assumed to make a decision to adopt apple management practices if the utility associated with that adoption choice $\left(U_{i 1}\right)$ is higher that the utility associated with the decision not to adopt $\left(U_{i 0}\right)$. However, the underlying utility function depends on household specific attributes, farm specific characteristics and institutional factors $(\mathrm{X})$ and a disturbance term having a zero mean: $U_{i 1}=x_{i} \beta_{i 1}+\varepsilon_{i 1}$ for adoption and $U_{i 0}=x_{i} \beta_{i 0}+\varepsilon_{i 0}$ for non-adoption. The farmer will therefore adopt if and only if $U_{i 1}>U_{i 0}$. This gives the probability of adoption as:

$P(Y=1 \mid x)=P\left(U_{i 1}>U_{i 0}\right)$

$P(Y=1 \mid x)=P\left(x_{i} \beta_{i 1}+\varepsilon_{i 1}>x_{i} \beta_{i 0}+\varepsilon_{i 0}\right)$

$P(Y=1 \mid x)=P\left(\varepsilon_{i 0}-\varepsilon_{i 1}<x_{i} \beta_{i 1}-x_{i} \beta_{i 0}\right)$

$P(Y=1 \mid x)=P\left(\varepsilon_{i}<\beta x_{i}\right)$

$P(Y=1 \mid x)=\emptyset(\beta x)$

Where $\emptyset$ is the cumulative distribution function of the standard normal distribution, $\beta s$ are parameters to be estimated by maximum likelihood method and $x$ is a vector of exogenous variables that determine adoption. For a normal distribution function, the model used to estimate the probability of observing a farmer utilizing apple 
management practices is given as:

$P(Y=1 \mid X)=\emptyset\left(x^{\prime} \beta\right)=\int_{-\infty}^{x^{\prime} \beta} \frac{1}{\sqrt{2 \Pi}} \exp \left(\frac{-z^{2}}{2}\right) d z$

Where $P\left(Y=1 \mid x_{i}\right)$ is the probability that the $i^{\text {th }}$ farmer has adopted apple management practices in a given season and $P\left(Y=0 \mid x_{i}\right)$ is the probability of non-adoption of apple management practices.

\subsubsection{Empirical Model Specification}

The econometric specification of the probit model is given in its latent as:

$Y_{i}^{*}=X_{i} \beta+\varepsilon_{i}$

Where $Y_{i}^{*}$ is a latent variable representing the dependent variable that defines farmer's binary (adoption) choices and depends on explanatory variables $\left(X_{i}\right)$ associated with farming household $i, \beta$ is a vector of parameters to be estimated, $\varepsilon_{i}$ is a standard normal distributed error term and symmetrically distributed about zero defined as: $\varepsilon \sim N(0,1)$. The relationship between the unobserved $\left(Y_{i}^{*}\right)$ and observed variable $\left(Y_{i}\right)$ is thus given as;

$\left\{Y_{i}=1\right.$, if $\left.Y_{i}^{*} \geq 0\right\}$

$\left\{Y_{i}=0\right.$, if $\left.Y_{i}^{*}<0\right\}$

The probit model has characteristic feature in that the effect of independent variables on the dependent variable is non-linear. In this present study, farmers' decision to adopt apple management practices was based on the underlying assumption of the utility function. Explicitly, the probit model below was estimated:

$P(Y=1 \mid x)=Y=\gamma+\beta_{1} x_{1}+\beta_{2} x_{2}+\cdots+\beta_{12} x_{12}+\varepsilon_{i}$

Where, $P(Y=1 \mid x)$ is the probability score of farmers' decision to adopt a management practice and $x_{s}$ are the explanatory variables. The specified probit model was however subjected to diagnostic checks. The variables used in the model and their measurements are given in Table 2.

\subsubsection{Estimation procedure}

The probit model was estimated using Maximum Likelihood Estimation (MLE) in STATA Version 14. Maximum likelihood estimates are consistent, asymptotically normal and efficient.

\section{Results and Discussions}

\subsection{Farmers' socio-economic and demographic characteristics}

Results in Table 3 show that apple production in Southwestern Highlands is dominated by male farmers. Specifically, 93.1 and 73.9 percent of the adopters and non-adopters respectively were males. The results indicate that there were significantly more males among the apple adopters than non-adopters $(\mathrm{p}=0.057)$. These results generally indicate that males dominate apple production. This could be attributed to males' better access to and control over resources like land and finances that are needed for apple production.

In terms of credit accessibility, Table 3 indicates that about 48.3 and 52.2 percent of the adopters and nonadopters of apple management practices (AMPs) had access to credit from financial institutions respectively. However, the difference between adopters and non-adopters in terms of proportions of farmers having access to credit facilities was not statistically significant. Table 3 further shows that 27.6 and 52 percent of the adopters and non-adopters of AMPs had off farm income sources respectively. However, there was no significant difference between the two categories of apple farmers in terms off-farm income source.

With access to agricultural information, the results indicate that the proportion of adopters of AMPs who had access to agricultural information were about 79.3 compared to 91.7 percent for non-adopters. There was no significant difference between the adopters and non-adopters in terms of access to agricultural information. Regarding orchard location, 79.3 and 78.3 percent of the adopters and non-adopters of AMPs had their orchards located on hill tops (Table 3). However, there were no significant differences among adopters and non-adopters with regard to orchard location of the apple farmers.

Results in Table 3 further show that over 75 percent of the adopters and non-adopters of apple producers were affected by birds. However, the difference between the two categories of apple farmers in terms of obstruction by birds was not statistically significant at 5 percent level. About 35 and 30 percent of the adopters and non-adopters of AMPs respectively expressed concern of thieves interfering in their orchard operations. With regard to apple producers' age, adopters and non-adopters averaged 52 years. These findings about age seem to indicate that apple production enterprise is actually dominated by aging farmers. In terms of household labor force, there were no significant differences between the two categories of apple producers. Both categories apple producers had an average of six members in their households. This is slightly higher than the national average of about five (UBOS, 2017). Education as measured by the years of schooling, both the adopters and non-adopters on average had 9 and 10 years of schooling respectively and there was no statistically significant difference between the two categories of apple farmers (Table 3 ). 
The size of land allocated to apple production by both adopters and non-adopters averaging 1.5 and 1.1 hectares respectively show that apple production is generally on small-scale mainly because of arable land scarcity that characterizes the Southwestern Highlands. This further implies that efforts to increase supply of apple fruits in the region need to focus on increasing productivity in a context of limited arable land. Lastly, average number of fruits per tree for adopters and non-adopters were 152 and 72 respectively and the difference average number of fruits per tree between the two categories of farmers was statistically significant at 1 percent level. The above socio-economic, farm-specific and institutional variables play an important role in determining the farmers' choices of the management practices as identified in Table 4.

\subsection{Apple Management Practices by farmers in Southwestern Highlands}

The study sought to identify the practices that are applied in the management of apple orchards with a view of documenting cost effective approaches of enhancing productivity for wider adoption of apple enterprises. Results from Table 4 show that more than half of the apple farmers were doing most of the recommended practices apart from fruit thinning, inorganic fertilizer application and mulching. Limited or no thinning of apple fruits as a management practice compromises yields and ultimately affects profits to the farmers.

Most of the commonly applied management practices included weeding, bending and staking, pesticide application and defoliation. All farmers from Rukungiri were doing routine weeding of their orchards followed by Kanungu, then Kabale and lastly Kisoro district (Table 4). The high proportion of farmers doing routine weeding translates into increased management costs. The high frequency of weeding may be attributed to the less adoption of other practices such as mulching that are useful in choking the weeds besides providing manure and maintaining soil moisture.

Regarding staking and bending of apple trees in Table 4, almost all the farmers from the four districts were staking their apple trees (78.9\%) most of whom hail from Rukungiri district and the least number of farmers were from Kanungu district. A total of 73.1 percent of all the farmers involved in the study from the four districts were applying pesticides in their apple orchards. This implies that 26.9 percent of the farmers were not applying any pesticides on their orchards. During the focus group interviews, some farmers from Kanungu reportedly spent a whole year without applying any pesticides on their apple farms and yet they complained of various crop and pest problems. As result, some farmers were planning to abandon their apple enterprises because they were not productive. With regard to defoliation, 61.5 percent of the farmers from the four districts were defoliating their apple trees. According to focus group discussions, some farmers were doing defoliation more than what is recommended, translating into high management costs which reduces the farmers' profit margin.

\subsection{Diagnostic tests}

Results from the Maximum Likelihood Estimation (MLE) shown in Table 7 for the probit model were subjected to diagnostic checks.

\subsubsection{Multicollinearity}

Diagnostic test for multicollinearity which is a common problem in any regression analysis was conducted based on variance inflation factor (VIF). The test results indicated that the largest value in the probit model was below the maximum value of 10 used as a rule of thumb to indicate presence of multicollinearity (Neter et al., 1990) and the average VIF for all variables should not exceed 5 (Ender, 2010). This indicates that multicollinearity is not a problem in the estimated probit model (Table 5).

\subsubsection{Model Specification Error}

The probit model was also checked for adequacy to ensure that it assumed the correct functional form. Results from link test for model specification in Table 6 reveals that in the probit regression model, the $\mathrm{P}$-value $(\mathbf{p}=$ 0.966) of hat squared was not significant at 5 percent level of significance. This implies that there are no specification errors in the estimating equation hence the probit model is correctly specified.

\subsubsection{Heteroscedasticity}

Heteroscedasticity, a common problem with most cross-sectional data was also tested. The established procedure for correction of heteroscedasticity is to estimate models using robust standard errors. Hence the probit model was estimated using robust standard errors to control for heteroscedasticity (Table 7).

\subsection{Factors influencing farmer's decision to adopt apple management practices}

Table 7 shows probit results for analyses of the factors influencing farmers' decision to adopt apple management practices (AMPs). The pseudo adjusted coefficient of determination shows that the model explained 68.9 percent of the variations in the probability. The result of the Wald chi-square for the probit model was found to be significant at 5 percent suggesting that the explanatory variables jointly explained the probability of a farmer's decision to adopt AMPs. The significance of the Wald chi-square further confirms that probit model for apple farmers fit well the data. The estimated model coefficients associated with $p$-values $(p>|z|)$ and the marginal 
effects of the explanatory variables selected for predicting farmer's adoption decision are presented in Table 7 . The variables that significantly influenced the decision to adopt the practices were found to be; sex of the farmer, age, household labor force, size of the farm, location of the orchard, access to credit facilities, access to agricultural information, influence of birds, average number of fruits per tree and income from non-farm sources.

Results in Table 7 indicated that sex of the farmer had a positive and statistically significant influence on the decision to adopt apple management practices at 1 percent level of significance. The marginal effect of sex of the farmer of 0.991 implies that more males than females would increase the probability of adopting apple management practices by 99.1 percent holding other factors constant. This is attributed to the fact that males and male headed households are relatively more influential and endowed with production of resources especially land and can therefore potentially allocate more land to production and management of apples than their female counter parts. These results concur with a study done by Lavison (2013), Obisesan (2014) and Mwangi and Kariuki (2015) who found that male farmers were more likely to adopt improved technologies and the associated management practices.

The marginal effect of age of the farmer was found to be statistically significant at 5 percent level. The corresponding marginal effect of -0.008 implies that one unit increase in years of the apple farmer would decrease the probability of a farmer decision to adopt apple management practices by about 0.8 percent holding other factors constant (Table 7). This might be because older farmers are used to traditional practices and find it difficult to adjust to modern management practices that may require more attention, concentration, time and ability that the more aged may be lacking. These findings are in line with Ghimire and Kafle (2014) study among apple farmers in Nepal and Udimal et al. (2017) among rice farmers in Ghana that older farmers are averse to technology adoption.

Model results from Table 7 suggest that a household comprising of economically active family members have more chances of adopting AMPs while establishing and maintaining apple orchards than those with a smaller family size as witnessed by a positive coefficient at 5percent level of significance. The marginal effect of 0.076 for household size implies that any additional increase in every one person of economically active family member would increase apple adoption management practices by 7.6 percent holding other factors constant. This finding agrees to theoretical expectations as seen in Elias et al. (2016) study in Ethiopia while analyzing farmers' satisfaction with agricultural extension services.

Farm characteristics play an imperative role in the decision making process to adopt best management practices, among the major ones being farm size (Liu et al., 2018). This study explored the influence of farm size on a farmer decision to adopt AMPs. It was found out that an increase in the size of the apple farm had a positive influence on the decision to adopt AMP at 5 percent level of significance. The marginal effect of 0.082 for the size of the apple farm means that any additional increase in apple acreage increases the probability of the decision to adopt AMP by 8.2 percent other factors held constant (Table 7). These findings are in tandem with most empirical literature and studies conducted by Abubakar et al. (2016), Singh and Varshney (2016) and Chandio and Yuansheng (2018) who observed that producers operating on large sized farms are more likely to adopt better management practices, willing to invest in modern technology, possess more resource inputs for investment and take into consideration the environmental concerns.

The location of the orchard was found to be a statistically significant factor in influencing the farmers' decision to adopt the AMPs at 5 percent. The marginal effect of -0.167 implies that farmers with orchards located on the hill tops have a reduced chances of adopting the management practices by 16.7 percent (Table 7). This could be attributed to the fact that such farms are susceptible to vagaries of weather, soil erosion and poor soil fertility. Additionally, the orchards are associated with poor tree quality characteristics and lower apple yields. This evidence suggests that planting apple trees on hilltops is not the best commercial alternative for higher apple yields in Southwestern Highlands. However, these results disagree with a study by Hadoto (2001) in Uganda who found out that presence of fertile soils on gentle slopes could be responsible for the high yields since they support the growth of cultivars.

Access to credit was found to have a positive and statistically significant influence on farmers' decision to adopt AMPs at 5 percent level. The marginal effect of 0.229 implies that famers who had access to credit compared to those that didn't, had an increased chance of adopting the practices by about 22.9 percent (Table 7). This could be due to the fact that credit acquisition enables farming households to acquire productivity enhancing inputs and other services capable of transforming apple enterprises. Similar findings have also been observed by Chandio and Yuansheng (2018) in Pakistan and Elias et al. (2016) in Ethiopia who found out that credit access enhances the adoption of improved varieties and other inputs such as inorganic fertilizers which are essential for increased production. On the contrary, Teklewold et al. (2013) study in Ethiopia revealed that credit constrained households were less likely to use improved varieties such as inorganic fertilizers.

More so, the influence of access to agricultural information on farmers' decision to adopt AMPs was negative and statistically significant at 5 percent level (Table 7). Specifically, apple farmers who had access to agricultural information were about 5.2 percent less likely to adopt AMPs. This could be attributed to the fact 
that information access without regular contact of extension workers may not facilitate adoption of improved management practices. This is in agreement with Cole and Fernando (2014) study in India who found out that farmers with access to agricultural information without understanding it technically may not derive gains from agricultural knowledge. However, the findings are contrary to those of Abdul-Salam and Phimister (2015) study in Ethiopia and Chandio and Yuansheng (2018) in Pakistan.

Results in Table 7 indicate that an apple farmer that had obstruction from birds in their orchards had a reduced likelihood of adopting AMPs by 13.2 percent compared to their counterparts. This could be due to the fact that birds damage a large number of apple fruits resulting into more wastage. This is supported by Adima et al. (2016) study in Uganda who found out that presence of pests such as birds discourage farmers from applying productivity enhancing management practices because of the costs involved.

Average number of fruits per tree was found to have a positive and significant influence on farmers' decision to adopt AMPs at 1 percent. The marginal effect of 0.003 implies that additional increase in the number of fruits per tree increases the chance of a farmer to adopt an AMP holding other factors constant (Table 7). The findings of this study are supported by Rahman et al. (2018) in Bangladesh who found out that adoption of improved varieties was associated with higher productivity.

Results in Table 7 show that apple farmers who had one or more sources of off-farm income were 32 percent less likely to adopt AMPs than those who solely depended on agriculture for income at 5 percent level. This is not surprising due to the fact that if group of apple farmers engages in off-farm work, there might be competition for cheap labor to take care most of the production activities. This is line with Onyenekwe and Okorji (2015) who observed that in Ethiopia, off-farm income sources enhanced farm production suggesting that the income sources had spillover effects on on-farm activities. Our findings however differ from those of Elias et al. (2016) who found out that off-farm work positively influenced farmers' satisfaction with extension services in Ethiopia.

\section{Conclusions and Policy Implications}

The findings and discussions point out that both socio-economic, farm specific characteristics and institutional factors played an important role in the farmer decision to adopt apple management practices. The most commonly applied apple management practices were found to be; weeding, bending and staking, pesticide application and defoliation. The key factors that influenced farmers' decision to adopt AMPs were; sex of the farmer, age of the farmer, household labor force, farm size, orchard location, off-farm income source, average number of fruits per tree, access to credit, access to agricultural information and obstruction by pests especially birds.

Gender responsive programs that recognize women participation as apple producers need to be explored as part of the efforts to enhance wider adoption of apple management practices. Such strategies could include; sensitization of female farmers and provide them with incentives such as credit, agro-inputs to engage in apple production. Research needs to come up with a sustainable but affordable remedy against birds. This might require assessment of the different methods such as fruit bagging used by farmers in the region and beyond so that a cost effective and environmentally friendly method of dealing with birds can be identified and disseminated among farmers. Additionally, there is need to explore appropriate and cost effective avenues for credit access. This requires extension and research to organize farmers in groups so as to access credit at reasonable terms from the rural financial institutions. Lastly, strategies of attracting and maintaining youth into apple farming need to be explored and implemented since apple farming is a labor intensive crop that is dominated by aging farmers.

\section{References}

Abdul-Salam, Y., \& Phimister, E. (2015). Efficiency Effects of Access to Information on Small Scale Agriculture: Empirical Evidence from Uganda. Paper Presented at the 89th Annual Conference, April 13-15, 2015, Warwick University, Coventry, UK.

Abubakar, H. N., Kolo, I. N., Yabagi, A. A., \& Garba, Y. (2016). Adoption of Production Technologies by Lowland Rice Farmers in Lavun Local Government Areas of Niger State, Nigeria. International Journal of Agricultural Extension, 4(1), 49-56.

Adima, E. G., Wodada W, \& Wasukira, A. (2016). Apple Orchards and Farmers Practices in Their Management in Mt. Elgon Subzone of Eastern Uganda. Journal of Biology, Agriculture and Healthcare, 6(24).

Aheisibwe, A. R., Etiang, J., Ashaba, D., Kwikiriza, G., Mwesige, R., Muhereze, R., \& Barekye, A. (2017). Profitability of Apple Enterprise among Small-Holder Farmers in South Western Highland Agro-Ecological Zone (Swhaez) of Uganda. Journal of Development and Agricultural Economics, 9(7), 190-199.

Busdieker-Jesse, N. L., Nogueira, L., Onal, H., \& Bullock, D. S. (2016). The Economic Impact of New Technology Adoption on the US Apple Industry. Journal of Agricultural and Resource Economics, 41(3):549-569. 
Byarugaba, A. A., Gard, T., \& Kashaija, I. N. (2013). Prevalence of Apple Scab and Powdery Mildew Infecting Apples in Uganda and Effectiveness of Available Fungicides for Their Management. African Journal of Agricultural Research, 8(18), 2063-2067.

Chandio, A. A., \& Yuansheng, J. (2018). Determinants of Adoption of Improved Rice Varieties in Northern Sindh, Pakistan. Rice Science, 25(2), 103-110.

Chemining'wa, G., Mulagoli, I., Mwonga, S., Ndubi, J., Tum, J., \& Turyamureeba, G. (2005). Kabale Apples: Boom or Burst? A Study to Develop Strategies to Exploit Market Opportunities for Apple Farmers in Kabale, Uganda Pp. 23-24.

Cole, S. A., \& Fernando, A. N. (2014). The Value of Advice: Evidence from the Adoption of Agricultural Practices. HBS Working Group Paper, 1(1.3), 6.

Elias, A., Nohmi, M., Yasunobu, K., \& Ishida, A. (2016). Farmers' Satisfaction with Agricultural Extension Service and Its Influencing Factors: A Case Study in North West Ethiopia. Journal of Agricultural Science and Technology, 18(1), 39-53.

Ender. (2010). “A Statistical Framework for Boosting Decision Rules”, Data Mining and Knowledge Discovery, Vol. 21 No. 1, Pp. 52-90.

Fadare, O. A., Akerele, D., \& Toritseju, B. (2014). Factors Influencing Adoption Decisions of Maize Farmers in Nigeria. International Journal of Food and Agricultural Economics, 2(3), 45.

FAO. ( 2016). FAOSTAT Production Database [2016-3-15]. http:// faostat.fao.org.

FAOSTAT. (2013). Food and Agriculture Organization Statistical Database, United Nations, Rome, Italy. Fish and Wildlife Service, Arlington, Va. 18 P.

Ghimire, B., \& Kafle, N. (2014). Integrated Pest Management Practice and Its Adoption Determinants among Apple Farmers in Mustang District of Nepal. Scholars Journal of Agriculture and Veterinary Sciences, 1(2), 83-89.

Hadoto, D. (2001). In: Mukiibi (Ed). Agriculture in Uganda - General Information. NARO-Uganda. Geology. Pp. 33-65.

ICRAF. (2003b). Temperate Fruits Go Tropical: Apples, Peaches, Pears and Plums Take to the Hills of Uganda. ICRAF, Nairobi, Kenya.

Kashaija, I. N., \& Wagoire, W. (2008). Farming Systems and Livelihood Analysis of the South-Western Highlands Agro-Ecological Zone: A Report. Kachwekano Zonal Agricultural Research and Development Institute, Kabale, p113.

Lavison, R. (2013). Factors Influencing the Adoption of Organic Fertilizers in Vegetable Production in Accra, Msc Thesis, ACCRA, Ghana.

Liu, T., Bruins, R. J., \& Heberling, M. T. (2018). Factors Influencing Farmers' Adoption of Best Management Practices: A Review and Synthesis. Sustainability, 10(2), 432.

Ministry of Agriculture Animal Industry \& Fisheries [MAAIF]. (2012). Proposed Plan to Operationalise the Non-ATAAS Component of the Agriculture Sector Development Strategy and Investment Plan (2010/20112014/2015). Kampala, Uganda.

Mwangi, M., \& Kariuki, S. (2015). Factors Determining Adoption of New Agricultural Technology by Smallholder Farmers in Developing Countries. Journal of Economics and Sustainable Development, 6(5).

Namirembe, S., Obua, J., \& Nyeko, P. (2006). Agroforestry for Development in Uganda. A Synthesis of Topics Discussed at the $2^{\text {nd }}$ National Agroforestry Workshop, September 2001. Nairobi, Kenya.

Neter, J., Wasserman, W., \& Kutner, M. H. (1990). Applied Linear Statistical Models, $3^{\text {rd }}$ Ed., Irwin, Boston, Ma.

Obisesan, A. (2014). Gender Differences in Technology Adoption and Welfare Impact among Nigerian Farming Households, MPRA Paper No. 58920

Onyenekwe, S. C., \& Okorji, E. C. (2015). Effects of Off-Farm Work on Technical Efficiency of Rice Farmers in Enugu State, Nigeria. Journal of Agricultural Economics and Development, 4(4), 044-050.

Rahman, S., Matin, M., \& Hasan, M. (2018). Joint Determination of Improved Variety Adoption, Productivity and Efficiency of Pulse Production in Bangladesh: A Sample-Selection Stochastic Frontier Approach. Agriculture, 8(7), 98.

Singh, P., \& Varshney, J. G. (2016). Adoption Level and Constraints in Rice Production Technology. Indian Research Journal of Extension Education, 10(1), 91-94.

Subedi, S., Ghimire, Y. N., \& Devkota, D. (2017). Socio-Economic Assessment on Maize Production and Adoption of Open Pollinated Improved Varieties in Dang, Nepal. Journal of Maize Research and Development, 3(1), 17-27.

Teklewold, H., Kassie, M., \& Shiferaw, B. (2013). Adoption of Multiple Sustainable Agricultural Practices in Rural Ethiopia. Journal of agricultural economics, 64(3), 597-623.

Turyomurugyendo, L., Boffa, J., \& Hakiza, J. (2004). Introduction of Deciduous Fruit Tree Growing in the Tropical Highlands of Kabale, Uganda. Uganda Journal of Agricultural Sciences, 9(1), 470-479. 
Uganda Bureau of Statistics [UBOS] (2017). Uganda National Household Survey, 2016/2017. Kampala, Uganda. .

Udimal, T. B., Zhuang, J., Owusu, S. M., \& Ayamba, E. C. (2017). Factors Influencing the Agricultural Technology Adoption: The Case of Improved Rice Varieties (Nerica) in the Northern Region,Ghana. Journal of Economics and Sustainable Development, 8(8).

Wang, N., Wolf, J., \& Zhang, F. S. (2016). Towards Sustainable Intensification of Apple Production in ChinaYield Gaps and Nutrient Use Efficiency in Apple Farming Systems. Journal of integrative agriculture, 15(4), 716-725.

Wooldridge, J. M. (2010). Econometric Analysis of Cross Section and Panel Data: MIT press.

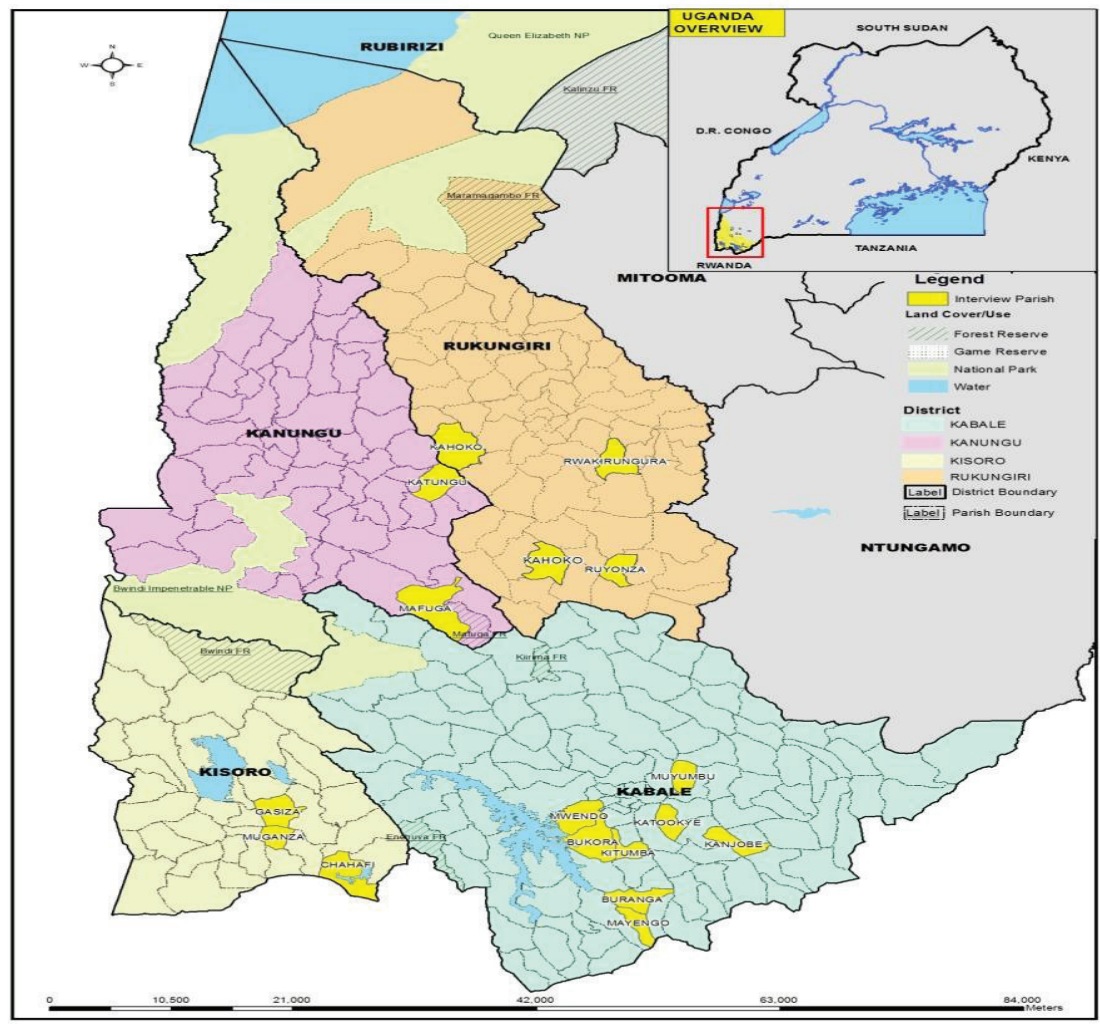

Figure 1: Study areas 
Table 1: Number of Apple farmers selected from each Parish

\begin{tabular}{|c|c|c|c|c|}
\hline Districts & Sub counties & Parishes & Target Apple farmers & Sampled Apple farmers \\
\hline \multirow[t]{4}{*}{ Kisoro } & \multirow[t]{2}{*}{ Nyakabande } & Gisoroza & 04 & 02 \\
\hline & & Gisiza & 04 & 02 \\
\hline & \multirow[t]{2}{*}{ Mulora } & Kibumba & 02 & 01 \\
\hline & & Chahafi & 02 & 01 \\
\hline \multirow[t]{10}{*}{ Kabale } & \multirow[t]{2}{*}{ Kyanamira } & Katokye & 06 & 03 \\
\hline & & Muyumbu & 07 & 04 \\
\hline & \multirow[t]{2}{*}{ Kitumba } & Bukoora & 06 & 03 \\
\hline & & Mwendo & 12 & 07 \\
\hline & \multirow{2}{*}{$\begin{array}{l}\text { Kabale } \\
\text { Municipality }\end{array}$} & Rushoroza & 04 & 02 \\
\hline & & Bugongi & 03 & 02 \\
\hline & \multirow[t]{2}{*}{ Maziba } & Kanjobe & 04 & 02 \\
\hline & & Nyanja & 06 & 02 \\
\hline & \multirow[t]{2}{*}{ Kamuganguzi } & Buranga & 06 & 03 \\
\hline & & Mukarangye & 06 & 03 \\
\hline \multirow[t]{4}{*}{ Rukungiri } & \multirow[t]{2}{*}{ Buyanja } & Rwakirungwa & 04 & 02 \\
\hline & & Muramba & 02 & 01 \\
\hline & \multirow[t]{2}{*}{ Nyakagyeme } & Kahooko & 03 & 02 \\
\hline & & Rushasha & 02 & 01 \\
\hline \multirow[t]{4}{*}{ Kanungu } & \multirow[t]{2}{*}{ Rutenga } & Mafuga & 05 & 02 \\
\hline & & Katojo & 04 & 02 \\
\hline & \multirow[t]{2}{*}{ Rugyeyo } & Nyarurambi & 05 & 02 \\
\hline & & Katungu & 03 & 02 \\
\hline \multicolumn{2}{|l|}{ Total } & & 100 & 52 \\
\hline
\end{tabular}

Source: Field Data, 2017

Table 2: Statistical descriptions of variables used in the probit model specified

\begin{tabular}{|l|l|l|c|}
\hline Variables & Description & Units of measure & $\begin{array}{c}\text { Expected } \\
\text { sign }\end{array}$ \\
\hline $\begin{array}{c}\text { Dependent variable } \\
\left(Y_{i}\right)\end{array}$ & Apple adoption decision & $\begin{array}{c}Y_{i}=1 \\
\text { for adopters and } \\
\text { farmer is a non-adopter. }\end{array}$ & if a \\
\hline Independent variables & & & $1=$ male, $0=$ female \\
\hline$x_{1}$ & Sex of the farmer & Years & $+/-$ \\
\hline$x_{2}$ & Age of the apple farmer & Number & + \\
\hline$x_{3}$ & Household labor force & Years of schooling & + \\
\hline$x_{4}$ & Education level of the farmer & Hectares & + \\
\hline$x_{5}$ & Farm size & $1=$ Hilltop $0=$ Gentle slope & - \\
\hline$x_{6}$ & Orchard location & $1=$ Accessed, $0=$ Never & + \\
\hline$x_{7}$ & Access to Credit & $1=$ Accessed, $0=$ Never & + \\
\hline$x_{8}$ & Access to agricultural information & $1=$ Birds obstructed, $0=$ Never & - \\
\hline$x_{9}$ & Obstruction of birds & Numbers & + \\
\hline$x_{10}$ & Average number of fruits/ tree & $1=$ Interfered $0=$ Never & - \\
\hline$x_{11}$ & Thieves & $1=$ Had access, $0=$ Never & + \\
\hline$x_{12}$ & Off- farm Income source & & + \\
\hline
\end{tabular}


Table 3: Descriptive statistics for socio-economic and farm specific variables in Southwestern Highlands.

\begin{tabular}{|c|c|c|c|c|c|c|}
\hline \multirow[t]{2}{*}{ Variable } & \multirow[t]{2}{*}{ Units or Value } & \multicolumn{2}{|c|}{ Adopters } & Non-Adopters & \multirow{2}{*}{$\begin{array}{l}\text { Chi-sq } \\
\left(\chi^{2}\right)\end{array}$} & \multirow[t]{2}{*}{ P-value } \\
\hline & & \multicolumn{2}{|c|}{ Percent $(\%)$} & Percent (\%) & & \\
\hline Sex of the producer & $\begin{array}{l}1=\text { Male } \\
0=\text { female }\end{array}$ & \multicolumn{2}{|c|}{93.10} & 73.91 & 3.629 & 0.057 \\
\hline Credit access & $\begin{array}{l}1=\text { had access } \\
0=\text { never }\end{array}$ & \multicolumn{2}{|c|}{48.28} & 51.72 & 0.957 & 0.328 \\
\hline Off-farm income source & $\begin{array}{l}1=\text { had access } \\
0=\text { never }\end{array}$ & \multicolumn{2}{|c|}{27.57} & 52.17 & 3.276 & 0.070 \\
\hline Agricultural info. access & $\begin{array}{l}1=\text { had access } \\
0=\text { never }\end{array}$ & \multicolumn{2}{|c|}{79.31} & 91.73 & 1.418 & 0.234 \\
\hline Orchard Location & $\begin{array}{l}\text { 1=Hilltop, } \\
0 \text { otherwise }\end{array}$ & \multicolumn{2}{|c|}{79.31} & 78.26 & 0.009 & 0.927 \\
\hline Birds & $\begin{array}{l}1=\text { Obstructed } \\
0=\text { never }\end{array}$ & \multicolumn{2}{|c|}{75.86} & 86.96 & 1.017 & 0.313 \\
\hline \multirow[t]{2}{*}{ Thieves } & $1=$ Interfered & \multicolumn{2}{|c|}{34.48} & 30.43 & 0.096 & 0.757 \\
\hline & & Mean & Std. Dev & Mean & Std. Dev & P-value \\
\hline Age & Years & 56.0 & 12.64 & 58.0 & 12.59 & 0.407 \\
\hline Household Labor & Persons & 6.0 & 2.93 & 6.0 & 1.97 & 0.269 \\
\hline Education & Years in school & 9.0 & 5.77 & 10 & 4.64 & 0.669 \\
\hline Farm size & Acres & 1.5 & 2.10 & 1.1 & 1.30 & 0.411 \\
\hline Average fruits/tree & Numbers & 152 & 120.75 & 72.0 & 58.81 & 0.005 \\
\hline
\end{tabular}

Source: Field Data, 2017

Table 4: Apple Management Practices by farmers in Southwestern Highlands

\begin{tabular}{|c|c|c|c|c|}
\hline Management Practice & District & Frequency & Percentage (\%) & Overall (\%) \\
\hline \multirow{4}{*}{ Weeding } & Kabale $(n=32)$ & 26 & 81.30 & \multirow{4}{*}{$43(82.7)$} \\
\hline & Kanungu $(\mathrm{n}=8)$ & 7 & 87.50 & \\
\hline & Kisoro $(n=6)$ & 4 & 66.70 & \\
\hline & Rukungiri $(n=6)$ & 6 & 100.0 & \\
\hline \multirow{4}{*}{ Staking and Bending } & Kabale $(n=32)$ & 26 & 81.30 & \multirow{4}{*}{ 41(78.9) } \\
\hline & Kanungu $(n=8)$ & 5 & 62.50 & \\
\hline & Kisoro $(n=6)$ & 4 & 66.7 & \\
\hline & Rukungiri $(n=6)$ & 6 & 100.0 & \\
\hline \multirow{4}{*}{ Pesticide Application } & Kabale $(n=32)$ & 23 & 71.9 & \multirow{4}{*}{$38(73.1)$} \\
\hline & Kanungu $(\mathrm{n}=8)$ & 5 & 62.5 & \\
\hline & Kisoro $(n=6)$ & 4 & 66.7 & \\
\hline & Rukungiri $(n=6)$ & 6 & 100.0 & \\
\hline \multirow{4}{*}{ Defoliation } & Kabale $(n=32)$ & 18 & 56.30 & \multirow{4}{*}{$32(61.5)$} \\
\hline & Kanungu $(n=8)$ & 6 & 75.0 & \\
\hline & Kisoro $(n=6)$ & 2 & 33.3 & \\
\hline & Rukungiri $(n=6)$ & 6 & 100.0 & \\
\hline \multirow{4}{*}{ Fruit Harvest Handling } & Kabale $(n=32)$ & 17 & 53.1 & \multirow{4}{*}{$31(59.6)$} \\
\hline & Kanungu $(n=8)$ & 5 & 62.5 & \\
\hline & Kisoro $(n=6)$ & 5 & 83.3 & \\
\hline & Rukungiri $(n=6)$ & 4 & 66.7 & \\
\hline \multirow{4}{*}{ Pruning } & Kabale $(n=32)$ & 20 & 62.50 & \multirow{4}{*}{$30(57.7)$} \\
\hline & Kanungu $(\mathrm{n}=8)$ & 4 & 50.0 & \\
\hline & Kisoro $(n=6)$ & 0 & 0.0 & \\
\hline & Rukungiri $(n=6)$ & 6 & 100.0 & \\
\hline \multirow{5}{*}{$\begin{array}{l}\text { Organic Manure } \\
\text { Application }\end{array}$} & Kabale $(n=32)$ & 17 & 53.1 & \multirow{4}{*}{$30(57.7)$} \\
\hline & Kanungu $(n=8)$ & 6 & 75.0 & \\
\hline & Kisoro $(n=6)$ & 3 & 50.0 & \\
\hline & Rukungiri $(\mathrm{n}=6)$ & 4 & 66.7 & \\
\hline & Kabale $(n=32)$ & 13 & 40.6 & \\
\hline
\end{tabular}




\begin{tabular}{|c|c|c|c|c|}
\hline Management Practice & District & Frequency & Percentage (\%) & Overall (\%) \\
\hline \multirow{3}{*}{ Mulching } & Kanungu $(\mathrm{n}=8)$ & 0 & 0.0 & \multirow[t]{3}{*}{$21(40.3)$} \\
\hline & Kisoro $(n=6)$ & 3 & 50.0 & \\
\hline & Rukungiri $(n=6)$ & 5 & 83.3 & \\
\hline \multirow{4}{*}{$\begin{array}{l}\text { Inorganic Fertilizer } \\
\text { Application }\end{array}$} & Kabale $(n=32)$ & 10 & 31.3 & \multirow{4}{*}{$20(38.5)$} \\
\hline & Kanungu $(\mathrm{n}=8)$ & 4 & 50.0 & \\
\hline & Kisoro $(n=6)$ & 2 & 33.3 & \\
\hline & Rukungiri $(n=6)$ & 4 & 66.7 & \\
\hline \multirow{4}{*}{ Fruit Thinning } & Kabale $(n=32)$ & 9 & 28.1 & \multirow{4}{*}{$15(28.9)$} \\
\hline & Kanungu $(\mathrm{n}=8)$ & 3 & 37.5 & \\
\hline & Kisoro $(n=6)$ & 0 & 0.0 & \\
\hline & Rukungiri $(n=6)$ & 3 & 50.0 & \\
\hline
\end{tabular}

Source: Field Data, 2017

Table 4: Apple Management Practices by farmers in Southwestern Highlands

\begin{tabular}{|c|c|c|c|c|}
\hline Management Practice & District & Frequency & Percentage (\%) & Overall (\%) \\
\hline \multirow{4}{*}{ Weeding } & Kabale $(n=32)$ & 26 & 81.30 & \multirow{4}{*}{$43(82.7)$} \\
\hline & Kanungu $(\mathrm{n}=8)$ & 7 & 87.50 & \\
\hline & Kisoro $(n=6)$ & 4 & 66.70 & \\
\hline & Rukungiri $(n=6)$ & 6 & 100.0 & \\
\hline \multirow{4}{*}{ Staking and Bending } & Kabale $(n=32)$ & 26 & 81.30 & \multirow{4}{*}{ 41(78.9) } \\
\hline & Kanungu $(n=8)$ & 5 & 62.50 & \\
\hline & Kisoro $(n=6)$ & 4 & 66.7 & \\
\hline & Rukungiri $(n=6)$ & 6 & 100.0 & \\
\hline \multirow{4}{*}{ Pesticide Application } & Kabale $(n=32)$ & 23 & 71.9 & \multirow{4}{*}{$38(73.1)$} \\
\hline & Kanungu $(n=8)$ & 5 & 62.5 & \\
\hline & Kisoro $(n=6)$ & 4 & 66.7 & \\
\hline & Rukungiri $(n=6)$ & 6 & 100.0 & \\
\hline \multirow{4}{*}{ Defoliation } & Kabale $(n=32)$ & 18 & 56.30 & \multirow{4}{*}{$32(61.5)$} \\
\hline & Kanungu $(\mathrm{n}=8)$ & 6 & 75.0 & \\
\hline & Kisoro $(n=6)$ & 2 & 33.3 & \\
\hline & Rukungiri $(n=6)$ & 6 & 100.0 & \\
\hline \multirow{4}{*}{ Fruit Harvest Handling } & Kabale $(n=32)$ & 17 & 53.1 & \multirow{4}{*}{$31(59.6)$} \\
\hline & Kanungu $(n=8)$ & 5 & 62.5 & \\
\hline & Kisoro $(n=6)$ & 5 & 83.3 & \\
\hline & Rukungiri $(\mathrm{n}=6)$ & 4 & 66.7 & \\
\hline \multirow{4}{*}{ Pruning } & Kabale $(n=32)$ & 20 & 62.50 & \multirow{4}{*}{$30(57.7)$} \\
\hline & Kanungu $(\mathrm{n}=8)$ & 4 & 50.0 & \\
\hline & Kisoro $(n=6)$ & 0 & 0.0 & \\
\hline & Rukungiri $(n=6)$ & 6 & 100.0 & \\
\hline \multirow{4}{*}{$\begin{array}{l}\text { Organic Manure } \\
\text { Application }\end{array}$} & Kabale $(n=32)$ & 17 & 53.1 & \multirow{4}{*}{$30(57.7)$} \\
\hline & Kanungu $(n=8)$ & 6 & 75.0 & \\
\hline & Kisoro $(n=6)$ & 3 & 50.0 & \\
\hline & Rukungiri $(n=6)$ & 4 & 66.7 & \\
\hline \multirow{4}{*}{ Mulching } & Kabale $(n=32)$ & 13 & 40.6 & \multirow{4}{*}{$21(40.3)$} \\
\hline & Kanungu $(n=8)$ & 0 & 0.0 & \\
\hline & Kisoro $(n=6)$ & 3 & 50.0 & \\
\hline & Rukungiri $(n=6)$ & 5 & 83.3 & \\
\hline \multirow{4}{*}{$\begin{array}{l}\text { Inorganic Fertilizer } \\
\text { Application }\end{array}$} & Kabale $(n=32)$ & 10 & 31.3 & \multirow{4}{*}{$20(38.5)$} \\
\hline & Kanungu $(\mathrm{n}=8)$ & 4 & 50.0 & \\
\hline & Kisoro $(n=6)$ & 2 & 33.3 & \\
\hline & Rukungiri $(n=6)$ & 4 & 66.7 & \\
\hline \multirow{4}{*}{ Fruit Thinning } & Kabale $(n=32)$ & 9 & 28.1 & \multirow{4}{*}{$15(28.9)$} \\
\hline & Kanungu $(n=8)$ & 3 & 37.5 & \\
\hline & Kisoro $(n=6)$ & 0 & 0.0 & \\
\hline & Rukungiri $(n=6)$ & 3 & 50.0 & \\
\hline
\end{tabular}

Source: Field Data, 2017 
Table 5: Detection of multicollinearity problem

\begin{tabular}{|c|c|c|c|c|c|c|}
\hline \multicolumn{4}{|c|}{ Variable } & \multicolumn{2}{|c|}{$\begin{array}{c}\text { Variance Inflation factor } \\
\text { (VIF) }\end{array}$} & Tolerance (1/VIF) \\
\hline \multicolumn{4}{|l|}{ Age } & \multicolumn{2}{|c|}{1.380} & 0.727 \\
\hline \multicolumn{4}{|c|}{ Education } & \multicolumn{2}{|c|}{1.370} & 0.728 \\
\hline \multicolumn{4}{|c|}{ Influence of birds } & \multicolumn{2}{|c|}{1.330} & 0.754 \\
\hline \multicolumn{4}{|c|}{ Access to credit } & \multicolumn{2}{|c|}{1.300} & 0.767 \\
\hline \multicolumn{4}{|c|}{ Average number of fruits/tree } & \multicolumn{2}{|c|}{1.290} & 0.775 \\
\hline \multicolumn{4}{|c|}{ Orchard Location } & \multicolumn{2}{|c|}{1.290} & 0.775 \\
\hline \multicolumn{4}{|c|}{ Off-farm Income } & \multicolumn{2}{|c|}{1.280} & 0.784 \\
\hline \multicolumn{4}{|c|}{ Access to Agricultural Information } & \multicolumn{2}{|c|}{1.260} & 0.794 \\
\hline \multicolumn{4}{|c|}{ Farm size } & \multicolumn{2}{|c|}{1.170} & 0.856 \\
\hline \multicolumn{4}{|c|}{ Household Labor Force } & \multicolumn{2}{|c|}{1.160} & 0.865 \\
\hline \multicolumn{4}{|c|}{ Thieves } & \multicolumn{2}{|c|}{1.140} & 0.876 \\
\hline \multicolumn{4}{|c|}{ Sex } & \multicolumn{2}{|c|}{1.110} & 0.898 \\
\hline \multicolumn{4}{|c|}{ Mean VIF } & \multicolumn{2}{|c|}{1.260} & \\
\hline \multicolumn{7}{|c|}{ Table 6: Detection of Specification error problem } \\
\hline Adopt & Coef. & Std. Err. & $\mathbf{z}$ & $\mathbf{P}>\mathbf{z}$ & {$[95 \%$ Conf. } & Interval] \\
\hline _hat & 1.003 & 0.336 & 2.980 & 0.003 & 0.344 & 1.663 \\
\hline _hatsq & 0.010 & 0.222 & 0.040 & 0.966 & -0.426 & 0.445 \\
\hline cons & -0.008 & 0.365 & -0.020 & 0.982 & -0.724 & 0.708 \\
\hline
\end{tabular}

Table 7: Maximum Likelihood Estimation (MLE) Results of the Probit Model

\begin{tabular}{llcc}
\hline Variables & Coefficient & $\begin{array}{c}\text { Robust Std. } \\
\text { Err. }\end{array}$ & $\begin{array}{c}\text { Marginal Effects } \\
\text { (dy/dx) }\end{array}$ \\
\hline Constant & -1.071 & 1.806 & 0.991 \\
Sex & $5.252 * * *$ & 1.657 & -0.008 \\
Age & $-0.091 * *$ & 0.043 & 0.076 \\
Household Labor force & $0.870 * *$ & 0.374 & -0.003 \\
Education & -0.032 & 0.063 & 0.082 \\
Farm Size & $0.940 * *$ & 0.381 & -0.167 \\
Orchard Location & $-3.693 * *$ & 1.626 & 0.229 \\
Credit Access & $2.381 * *$ & 1.170 & -0.052 \\
Access to Agricultural Information & $-1.045 *$ & 0.604 & -0.132 \\
Obstruction of Birds & $-3.267 * *$ & 1.601 & 0.003 \\
Expected number of Fruits per Tree & $0.034 * * *$ & 0.010 & -0.200 \\
Thieves & -1.414 & 0.872 & -0.324 \\
Off-farm Income & $-2.118 * * *$ & 0.670 & \\
\hline Observations & 52 & & \\
Wald Chi(12) & 24.80 & & \\
Prob $>$ Chi & 0.016 & & \\
Log-likelihood & -11.103 & & \\
Pseudo R & & & \\
\hline \hline
\end{tabular}

Note: *, ** and *** show significance at 10, 5 and 1\% level, respectively 